http://dx.doi.org/10.4314/jae.v15i1.8

\title{
Maize Farmers' Perception of Commercialization and Privatization of Agricultural Extension Services in North Senatorial District of Gombe State, Nigeria
}

Sa'adatu B.A*., Usman S. and Dahiru. B.

National Agricultural Extension Research and Liaison Services (NAERLS) ABU

Zaria.

*Email Address:- mffaguji@hotmail.com

\begin{abstract}
A survey of maize farmers in Gombe north senatorial district of Gombe state was conducted in 2010 on their perception on commercialization and privatization of agricultural extension services. A structured questionnaire was used to collect data from 100 maize farmers, which were randomly selected. Descriptive statistics and binary probit model were the tools of analyses. The results indicate that majority (83\%) of the respondents were against commercialization and privatization of extension services. About $31 \%$ expressed willingness to pay economic rates only if qualitative and timely extension services would be provided. Moreover farm size, extension contact, educational level, membership of cooperative and access to credit were found significantly favouring commercialization and privatization of extension services. Additionally the main barriers to the acceptance of the idea by the farmers identified included high cost of other production inputs / low profit, poor quality of extension agents, high farmer -extension agent ratio and financial constraints. Therefore enhancing farmer's accessibility to qualitative extension services and affordable credit will help in promoting the commercializing and privatizing process of agricultural extension activities.
\end{abstract}

Key words: maize farmers, perception, commercialization, privatization, extension services

\section{INTRODUCTION}

Today commercialization and privatization ( $\mathrm{C}$ and $\mathrm{P}$ ) of agriculture is an inevitable reality throughout the whole World. There are a number of factors influencing the $\mathrm{C}$ and $\mathrm{P}$ process in agriculture. Some of them could be named as rapid growth of economies in the both developing, introduction of new technologies, market expansion, market liberalization, urbanization, rapid increase of demand for food, decreasing of farm population, liberalized and open economic policies, bilateral and multilateral economic agreements, developed infrastructural facilities in farming areas and government agricultural policies (Rohana and 
Bandara, 2006). Agricultural extension plays a major role in agricultural production which has a multiplier effects on the nonfarm sectors.

In Nigeria today, the issue of mismanagement and under/over-utilization of government's properties in the public sector and rapid increase in population in the country have resulted to huge wastage of resources, valuable properties and manpower potentials. This gave government no other option but to pursue quickly the $c$ and p programme. There are about 600 public enterprises in Nigeria run or controlled by the Federal Government. Many more are controlled by State Government (Matanmi et. al., 2008). The privatization and commercialization Decree of 1988 set up the Technical Committee on privatization and commercialization (TCPC) under the Chairmanship of Dr. Hamza Zayyad. The main thrust of the committee is to privatize 111 public enterprises and commercialize 34 others. In 1993, the TCPC concluded its assignment and submitted a final report. In 1999, the Federal Government enacted the public enterprise (privatization and commercialization) Act 1999, which created the National Council on privatization under the Chairmanship of the Vice-President of the Nation (Matanmi et. al., 2008).

Due to its relatively low and unimpressive performance record of public agricultural extension services in Nigeria, governments (federal and states) have been proposing to commercialize and privatize extension services in the country. This has attracted the attention of many researchers resulting to conduct of numerous and extensive researches on the issue. Among these works included Dimelu and Madukwe (2001), Ozor (2002), Ngwu (2004), Ozor et. al., (2007), Matanmi et al., (2008) and Ajieh et. al., (2008). A lot have been done in this area, but still there exists an information gap on the farmers' perception on $\mathrm{C}$ and $\mathrm{P}$ that produces the major important crops (e.g. maize) needed for the attainment of food security in the country. Hence, the main objectives of this study were to ascertain maize farmers' perception of $\mathrm{C}$ and $\mathrm{P}$ programme; determine the level of awareness of $\mathrm{C}$ and $\mathrm{P}$ programme; identify factors affecting their perceptions; and examine perceived obstacles to the success of the programme

Under the concept of commercialization of agricultural extension, the following points can be deduced. First, agricultural extension is considered as a commercial product or service, which exchanges between two parties over an agreed payment. Put simply, one party (extension providers) acts as sellers and other party (farmers) acts as buyers. Secondly, basic economic theory of supply and demand is applied in this process. Agricultural extension service becomes a totally demand-oriented activity. Thirdly, extension can also be considered as an input such as fertilizer, improved seed, agro-chemicals, machinery, etc, which is essential for the commercially oriented farming. As farmers have to pay for other inputs, they have to pay for extension services also (Rohana and Bandara, 2006). Depending on the extension approach, farmers should either pay totally or partially the extension services rendered to them.

According to Rohana and Bandara (2006) privatization is mainly changing the ownership of the extension service to private sector from public sector. Extension services have been mainly funded and delivered by government 
agencies free of charge for decades. Commercialization is not merely privatization as it does not need a change of ownership under commercialization. Ownership can be kept with the government or semi government organization, but the service is provided on a commercial basis. Under privatization, ownership should be changed into the hands of a private organization.

\section{METHODOLOGY}

This study is conducted in Gombe north senatorial district of Gombe state. Gombe north senatorial district is purposively chosen because is the largest district among the three senatorial districts in the State. It is made up of five local government areas (LGAs) out of the eleven LGAs of the state, namely Gombe, Dukku, Nafada, Funakaye, and kwami LGAs. The study targeted one hundred (100) maize farmers across the chosen senatorial district. Twenty maize farmers were randomly selected from the maize farmers' population of each LGA. A structured questionnaire was used to collect data for the study. Descriptive statistics and binary probit were used for the data analyses.

A probit model was used to test the factors that influence the perception of maize farmers on $\mathrm{C}$ and $\mathrm{P}$ of agricultural extension. $\mathrm{A}$ probit model is a statistical procedure developed to estimate the relationship between a dichotomous dependent variable and continuous explanatory variables. Probit models transform a dichotomous dependent variable into a probability. The dependent variable is categorical. Specifically, $Y$ is a discrete random variable that assumes one of two possible values: 0 if a farmer is against the $C$ and $P$ of extension services, and 1 if he choose for. The independent variables may be either continuous or discrete, but they are assumed to be non-stochastic (Scott, 1997).

The probit model used to test the relationships between the predictor variables and $\mathrm{C}$ and $\mathrm{P}$ may be summarized as follows:

$Y_{i}=\sum_{j=1}^{8} \beta X_{i}+e_{i}$

where: $Y i=$ dichotomous or binary choice random variable - maize farmer's decision - that takes the value of 1 when farmer $i$ choose for or 0 when otherwise. Thus, the qualitative response model determines the probability that a farmer $i$ with given attributes $X 1 i, X 2 i \ldots, X 8 i$ will choose for the $\mathrm{C}$ and $\mathrm{P}$ of agricultural extension services in favour of the alternative response that he against the issue. Coefficients $\beta 1, \beta 2 \ldots, \beta 8$ may be interpreted as the partial derivatives of the probability of choosing for the issue with respect to the independent variables, $X 1 i$, $X 2 i \ldots, X 8 i$. The exogenous variables $(X 1-X 8)$ included in the model respectively, were farm size (hectare), age of farmer (years), maize farming experience (years), household size, extension visits (dummy), education level (years), access to credit (dummy) and farmers' cooperative membership (dummy). 


\section{RESULTS AND DISCUSSION}

\section{Socio-economic characteristics of the respondents}

The socio-economic, demographic and Institutional characteristics of the respondents were analyzed and reproduced in Table 1 . The result indicated that the farm size of the respondents ranges from 0.07 to 1.42 hectares with a mean of 0.53 hectare, implying that maize is produce under small-scale and subsistence system. Most of the respondents fall between the age bracket of 30 and 70 years with a mean age of 46.9 years. This shows that the farmers are within active and productive age with a mean farming experience of 49 years. The average years of education among the farmers is 3 years with a standard deviation of about 3 years that indicates a high variability of years of schooling among the respondents.

\section{TABLE 1: Socioeconomic characteristic of farmers}

\begin{tabular}{lcccc}
\hline \multicolumn{1}{c}{ Variables } & Minimum & Maximum & Mean & Std Dev \\
\hline Farm size (ha) & 0.07 & 1.42 & 0.52 & 0.61 \\
Age (years) & 30.00 & 70.00 & 46.93 & 8.41 \\
Farming experience (years & 12.00 & 54.00 & 49.00 & 12.32 \\
Household size (persons) & 2.00 & 13.00 & 6.80 & 2.39 \\
Extension visits (dummy) & 0.00 & 1.00 & 0.39 & 0.42 \\
Education level (years) & 0.00 & 5.00 & 3.01 & 2.92 \\
Access to credit (dummy) & 0.00 & 1.00 & 0.43 & 0.50 \\
Membership of cooperative (dummy) & 0.00 & 1.00 & 0.72 & 0.45 \\
\hline
\end{tabular}

Source: Field survey, 2010

\section{Awareness of the $\mathbf{C}$ and $\mathbf{P}$ programme among the respondents}

As indicated on figure 1 below, almost all the sample farmers (95\%) were aware of the programme of $\mathrm{C}$ and $\mathrm{P}$ of extension services, while only small proportion $(5 \%)$ of the respondents that are not aware. Among the reasons highlighted for their unawareness were no extension agents' contact, poverty and illiteracy. The main sources of the information on $\mathrm{C}$ and $\mathrm{P}$ programme among the farmers were through extension agents (22\%), radio/television $(20 \%)$, friends/relatives (32\%) and market place (24\%) (Table 2). 
Fig 1. Awareness level of C \& P of Agric Extension among the respondents

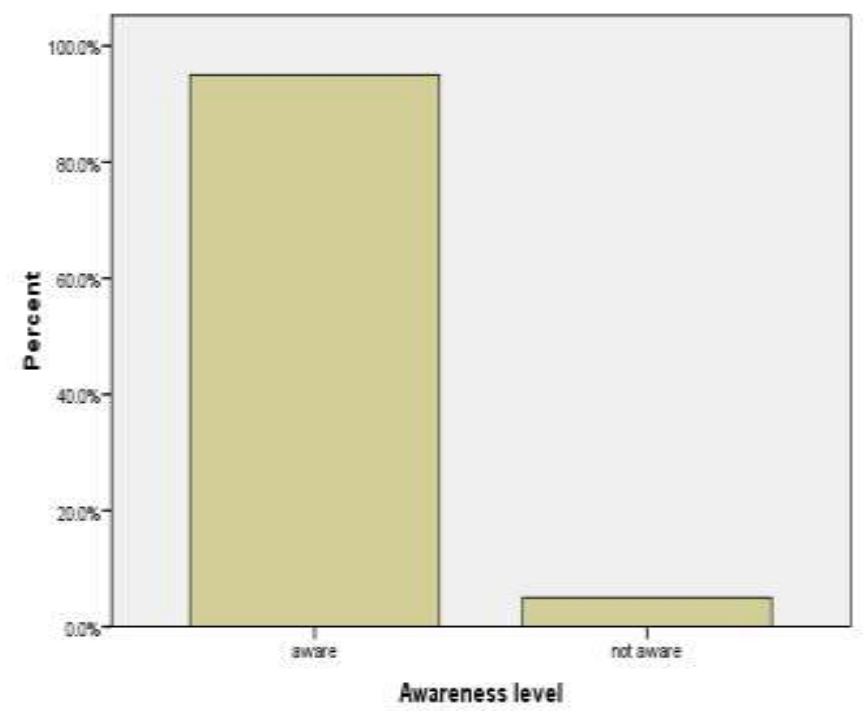

TABLE 2: Sources of information on $C$ and $P$ programme among the farmers

Sources of awareness

Extension agents

Radio/Television

Friends/relatives

Newspapers

Market place
Percentage $(n=100)$

22

20

32

2

24

\section{Perception and willingness to pay for extension services}

Table 3 indicates that most of the farmers (83\%) were not in support of $C$ and $\mathrm{P}$ of extension services, because they are not financially able to pay for enough basic production inputs like fertilizers, improved seeds, etc than to extension services if privatized. This finding agreed with that of Uzokwe and Ofuoku (2006) in which they found that majority (70\%) were not in support of privatization of agric extension services. Only $17 \%$ were in support of $C$ and $P$ programme, believing that it is the only way they can get better extension services. Farmers were asked if they can pay for the services at present extension system. Their responses were reproduced in Table 3 . From the table, the majority (45\%) were not willing to pay for any economic rates even if the extension system delivery is improved, but $7 \%$ and $31 \%$ were willing to pay unconditionally and if there is improvement respectively. 
TABLE 3: Farmers' perception and willingness to pay for extension services

\section{Perception}

For

Against

\section{Percentage $(n=100)$}

17

83

Willingness to pay for the services

Willing 7

Not willing 17

Willing, if improved 31

Not willing, even improved

Source: Field survey, 2010

\section{Factors affecting farmers' perception of $\mathrm{C}$ and $\mathrm{P}$ of agricultural extension services}

The estimated parameters for the maize farmers' perception of $\mathrm{C}$ and $\mathrm{P}$ of agricultural extension services in Gombe state of Nigeria is reproduced in Table 3. From the table, the chi square of the log likelihood function is statistically significant $(p<0.01)$, implying that the estimated model fitted the collected data well. The parameters of extension visits, education level and credit accessibility reveal that probability of farmers accepting the issue of $C$ and $P$ of extension services significantly increase $(p<0.01)$ as extension visits, education level and credit accessibility increase. Also, the parameters of farming experience and farm size indicate that probability of respondents accepting the issue significantly increase $(p<0.05)$ as these variables increase. Availability of credit eases the cash constraints and allows farmers to purchase inputs such as fertilizer, improved crop varieties and other inputs. This goes in line with the finding of Uzokwe and Ofuoku (2006) that extension visits and credit influence positively the acceptance of $C$ and P programme in Delta State. 
TABLE 3: Factors affecting perception of farmers on $C$ and $P$ of agric extension services

\begin{tabular}{|c|c|c|c|}
\hline Variable & Coefficient & Std error & t-ratio \\
\hline Constant & 1.760 & 1.060 & 1.640 \\
\hline Farm size $(x 1)$ & 0.218 & 0.094 & $2.273^{* *}$ \\
\hline Age $(x 2)$ & 0.055 & 0.032 & 1.725 \\
\hline Farming experience $(x 3)$ & 0.129 & 0.058 & $2.230^{* *}$ \\
\hline Household size (x4) & 0.022 & 0.171 & 0.127 \\
\hline Extension visits (x5) & 0.556 & 0.197 & $2.801^{* * *}$ \\
\hline Education level (x6) & 0.457 & 0.144 & $3.172^{\star \star \star}$ \\
\hline Access to credit (x7) & 0.329 & 0.056 & $5.874^{\star * *}$ \\
\hline Membership to cooperative (x8) & 0.044 & 0.389 & 0.191 \\
\hline Log likelihood function & \multicolumn{2}{|c|}{-41.287} & \\
\hline Restricted log likelihood & \multicolumn{2}{|c|}{-47.139} & \\
\hline Chi-squared & \multicolumn{2}{|c|}{$52.705^{\star * *}$} & \\
\hline
\end{tabular}

Source: Field survey, 2010. Note: ${ }^{* * *}$ and ${ }^{* *}$ significant at $! \%$ and $5 \%$ level of probability respectively

\section{Barriers to the process of $\mathrm{C}$ and $\mathrm{P}$ of Agricultural Extension as perceived by farmers}

The analysis of barriers to the process of $\mathrm{C}$ and $\mathrm{P}$ of agric extension in Gombe State reveals that there are three major constraints to the process. These are poor quality of extension agents $(25 \%)$, high cost of other production inputs/low profit (64.5\%) and low extension agent-farmers ratio $(9 \%)$. Others include conservativeness and financial constraints (Figure 2). Most of these constraints are associated with the system of production which are mainly traditional and subsistence method of production. This result is in line with the finding of Ajieh, et. al., (2008). From their study titled "constraints to privatization and commercialization of agricultural extension services as perceived by extension professionals and farmers", they found that fear of job insecurity among extension staff, insufficiently trained extension personnel and high level of subsistence farming were important constraints to effective $\mathrm{C}$ and $\mathrm{P}$ programme. 
Fig 2. Barriers to the process of $c \& p$ as perceived by the respondents

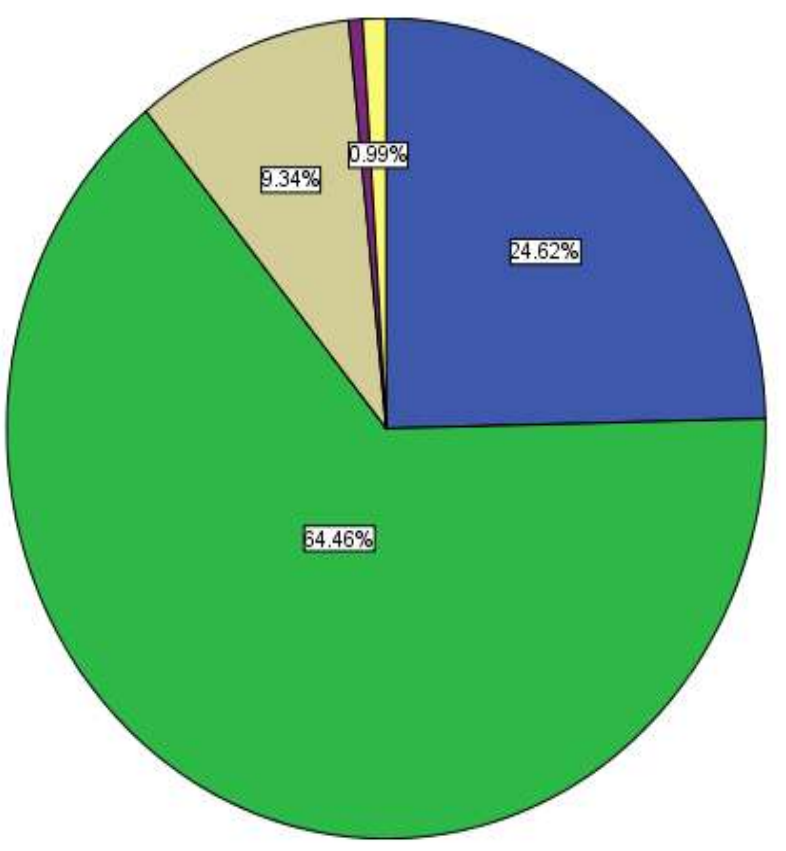

$\square$ poor quality of EAs

Inputs high cost/ow profit

Ghigh EA/farmers ratio

conservativeness

financial constraints

\section{CONCLUSION AND POLICY IMPLICATION}

The analysis of perception of farmers to $\mathrm{C}$ and $\mathrm{P}$ programme of extension services revealed that their perception level was very low even though their awareness level was very high. Extension contact, farming experience, education level, accessibility of credit and membership of farmers' cooperative were significant factors influencing the perception of farmers. While the main obstacles to impede the success of the programme were poor quality of extension agents, low profit, high farmers to extension agent ratio and poverty. Therefore, it is recommended that these factors influencing farmers' perception and constraints to the success of $\mathrm{C}$ and $\mathrm{P}$ programme should be given consideration by policymakers and relevant government authority before $\mathrm{C}$ and $\mathrm{P}$ of agricultural extension services is considered. 


\section{REFERENCES}

Ajieh, P. C., Agwu, A.E. and Anyanwu, A.C. (2008). Constraints to privatization and commercialization of agricultural extension services as perceived by extension professionals and farmers. African Journal of Agricultural Research Vol. 3 (5), pp. 343-347.

Dimelu M. U, Madukwe M. C. (2001). Extension workers' perception of privatization and commercialization of extension services in Enugu State, Nigeria. In: Olowu, T.A. (eds.). Proceedings of the 7th Annual National Conference of Agricultural Extension. Society of Nigeria (AESON) llorin, pp. $34-41$.

Matanmi, B.M, Adesiji, G.B. and Omokore, D.F. (2008). Need for Privatization of Agricultural Extension Services in Nigeria. Global Approaches to Extension Practice (GAEP), Vol. 4, No 2.

Ngwu GC (2004). Reaction of farmers to privatization and commercialization of agricultural extension services in Ebonyi State, Nigeria. M.Sc. Thesis: Department of Agricultural Extension, University of Nigeria, Nuskka.

Ozor, N. (2002). Extension professionals' perception of privatization and commercialization of agricultural extension service in Enugu State Agricultural Development Programme. M.Sc Research Project. Department of Agricultural Extension, University of Nigeria, Nsukka.

Ozor, N., Agwu A. E., Chukwuone N. A., Madukwe, M. C. and Garforth, C. J. (2007). Cost- sharing of Agricultural Technology Transfer in Nigeria: Perceptions of farmers and extension professionals. J.Agric. Edu. Ext. 13(1): 23-37.

Rohana P. M. and Bandara, R. M. A. S. (2006). Commercialization of Agriculture and Role of Agricultural Extension. Sabaragamuwa University Journal, vol 6, no. 1, pp 13-22.

Uzokwe, U. N. and Ofuoku, A. U. (2006). Farmers' Perception on Privatization and Commercialization of Agricultural Extension Services in Oshimili North and Sourth Local Government Areas of Delta State. Agricultural Journal 1 (4): $258-261$. 